Agricultural Journal 6(4): 131-133, 2011

ISSN: $1816-9155$

(C) Medwell Journals, 2011

\title{
Some Haemato-Biochemical Parameters of Sheep Pre-Treated with Levamisole and Transported by Road
}

\author{
${ }^{1}$ Mohammed Bisalla, ${ }^{2}$ Markus Bukar Bi-Allah and ${ }^{1}$ Frank Okechukwu Nnadiwa \\ ${ }^{1}$ Department of Veterinary Pathology and Microbiology, Ahmadu Bello University, \\ Zaria, Kaduna State, Nigeria \\ ${ }^{2}$ Abubakar Tatari Ali Polytechnic, Bauchi, Bauchi State, Nigeria
}

\begin{abstract}
The effect of levamisole pre-treatment on some haemato-biochemical parameters of transported sheep was investigated. Eight sheep of mixed sexes and aged between 1 and $1 \frac{1}{2}$ years were used in the study. The sheep were bled via jugular vene puncture prior to transportation and these served as control values. Levamisole was then administered at $15 \mathrm{mg} \mathrm{kg}^{-1}$ intramuscularly to each sheep. About $30 \mathrm{~min}$ after levamisole administration, the sheep were then transported for $260 \mathrm{~km}$ in a bus. The sheep were then off loaded and bled. This served as the experimental values. The PCV decreased significantly $(\mathrm{p}<0.05)$ post transportation from the control values. There were no significant changes $(p>0.05)$ in the mean values of total serum protein, total leukocyte values, absolute lymphocyte and absolute neutrophil values between the experimental and control groups. However, the serum albumin increased significantly $(\mathrm{p}<0.05)$ in the experimental when compared to the control values. Levamisole administered at $15 \mathrm{mg} \mathrm{kg}^{-1}$ intramuscularly $30 \mathrm{~min}$ before transportation of Yankasa sheep increased the level of serum albumin and the neutrophil lymphocyte ratio but did not alter the levels of total serum protein, leukocyte, lymphocyte and neutrophils post transportation.
\end{abstract}

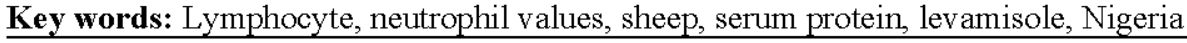

\section{INTRODUCTION}

Transportation of animals by road is very important in animal production and utilization. The intensity and specialization of livestock production and the demand for livestock to be marketed and slaughtered outside the places where they are being produced have necessitated animal transportation all over the world (Ayo and Oladele, 1996). Transportation is a severe stress and can predispose calves to bovine respiratory diseases such as shipping fever (Ziprin et al., 1980). Stress is physiologically mediated by an increase in the activity of the adrenal gland by increasing the synthesis of cortisol. Levamisole is the levo-rotatory form of tetramisole first described by Thienpont et al. (1966). It is an agonist of nicotinic acetylcholine receptors in nematode muscle and causes spastic paralysis (Atessahin et al., 2004).

Since 1971, tetramisole (a stearic isomer of levamisole hydrochloride) has been recognized as an immunomodulating drug which augmented the protective effect of a Brucella vaccine in mice (Symoens and Rosenthal, 1977). It is believed an immunomodulator restores cell mediated immune function in peripheral T-lymphocytes and phagocytosis by monocytes
(Naylor and Hadden, 2003). Levamisole is known to increase phagocytosis by polymorphonuclear leukocytes and macrophages in cases of a hypofunctional state of these cells (Vojtic, 1998). Levamisole administered at $6 \mathrm{mg} \mathrm{kg}^{-1}$ to unstressed calves at vaccination caused a decrease in antibody and cellular immune responses to bovine herpesvirus (Babiuk and Misra, 1982) but in a similar study using the same dose of levamisole in calves transported before treatment, an enhanced antibody response was observed (Babiuk and Misra, 1982).

The objective of this research was to determine the effects of levamisole administration before transportation on some haemato-biochemical parameters of sheep.

\section{MATERIALS AND METHODS}

Animals: Eight clinically healthy Yankasa sheep of mixed sexes, aged between 1 and $1 \frac{1}{2}$ years with a mean weight of $18.6 \mathrm{~kg}$ were used for the study.

Blood sampling: About $5 \mathrm{~mL}$ of blood was collected from each animal before transportation using a $5 \mathrm{~mL}$ syringe and a $22 \mathrm{G}$ needle to obtain control values, $2 \mathrm{~mL}$ into ethylene diamine tetra acetic acid tubes for haematological

Corresponding Author: Mohammed Bisalla, Department of Veterinary Pathology and Microbiology, Ahmadu Bello University, Zaria, Kaduna State, Nigeria 
Agric. J., 6 (4): 131-133, 2011

Table 1: Mean \pm SEM PCV (\%), Total Protein (TP) $\left(\mathrm{g} \mathrm{dL}^{-1}\right)$, total WBC $\left(\times 10^{3} \mu \mathrm{L}^{-1}\right)$, Absolute Lymphocytes $\left(\times 10^{3} \mu \mathrm{L}^{-1}\right)$ (AL) and Absolute Neutrophil counts $\left(\times 10^{3} \mu \mathrm{L}^{-1}\right)(\mathrm{AN})$ in Yankasa sheep administered levamisole and transported by road

\begin{tabular}{llllll}
\hline Parameters & $\mathrm{PCV}(\%)$ & $\mathrm{TP}\left(\mathrm{g} \mathrm{dL}^{-1}\right)$ & $\mathrm{WBC}\left(\times 10^{3} \mu \mathrm{L}^{-1}\right)$ & $\mathrm{AL}\left(\times 10^{3} \mu \mathrm{L}^{-1}\right)$ & $\mathrm{AN}\left(\times 10^{3} \mu \mathrm{L}^{-1}\right)$ \\
Pre transport & $32.25 \pm 0.92$ & $7.213 \pm 0.19$ & $8.275 \pm 1.21$ & $4.310 \pm 0.60$ & $3.715 \pm 0.76$ \\
Post transport & $27.75 \pm 1.24$ & $7.038 \pm 0.15$ & $9.875 \pm 1.90$ & $4.309 \pm 0.91$ & $5.613 \pm 1.28$ \\
p value & 0.0056 & 0.2449 & 0.2467 & 0.1120 & 0.4996 \\
\hline
\end{tabular}

analyses and $3 \mathrm{~mL}$ in to clean test tubes for serum harvest. The serum obtained was stored at $-20^{\circ} \mathrm{C}$ until analysed.

Levamisole administration: After bleeding, the sheep were then each administered with levamisole hydrochloride (Farvet ${ }^{\circledR}$, Holland) injection at $15 \mathrm{mg} \mathrm{kg}^{-1}$ body weight intramuscularly $30 \mathrm{~min}$ before transportation.

Transportation: The sheep were transported for a total distance of $260 \mathrm{~km}$ in a 10 seater bus by road mimicking the manner of small ruminant transportation in Northern Nigeria. The journey lasted about $3 \mathrm{~h}$. The sheep were then bled as described above after returning from the journey and offloading them. These served as the experimental values.

Sample analyses: Packed Cell Volume (PCV) was determined by the standard microcapillary method, total serum protein by the Biuret method and serum albumin by the Bromocresol green method. Total leukocyte count was determined by the Haemocytometer method and differential leukocyte were determined from Giemsa stained thin blood smears as described by Coles (1986). The neutrophil lymphocyte ratio was calculated.

Statistical analysis: Students' t-test using GraphPad prism Version 4.0 for windows from GraphPad software, San Diego, California, USA was employed to test levels of significance between the means obtained from the experimental compared to control values of $\mathrm{p}<0.05$.

\section{RESULTS}

The mean PCV in the control sheep dropped significantly $(\mathrm{p}<0.05$ ) from $32.25 \pm 0.92$ to $27.75 \pm 1.24 \%$ in the experimental group. The total serum protein decreased from the control value of 7.21-7.04 $\mathrm{g} \mathrm{L}^{-1}$ in the experimental group although, the decrease was not statistically significant ( $p>0.05)$. The total leukocyte count increased from the control value of $8.3 \pm 1.2\left(\times 10^{9} \mathrm{~L}^{-1}\right)$ to $9.9 \pm 1.9\left(\times 10^{9} \mathrm{~L}^{-1}\right)$ in the experimental group although, it was not statistically significant $(\mathrm{p}>0.05)$. The absolute lymphocyte count decreased from $4.3 \pm 0.6\left(\times 10^{9} \mathrm{~L}^{-1}\right)$ in the control to $4.3 \pm 0.9\left(\times 10^{9} \mathrm{~L}^{-1}\right)$ in the experimental group. The absolute neutrophil count increased from the control value of $3.71 \pm 0.8\left(\times 10^{9} \mathrm{~L}^{-1}\right)$ to a post transportation value of $5.6 \pm 1.2\left(\times 10^{9} \mathrm{~L}^{-1}\right)$. The observed increase was however not statistically significant $(p>0.05)$. The neutrophil lymphocyte ratio increased from the control value of $0.86 \pm 1.26$ to the experimental value of $1.3 \pm 1.39$. There were no observed changes in the absolute monocyte and eosinophil values (Table 1).

\section{DISCUSSION}

In the present study, there was an observed decrease in the PCV in sheep pre-treated with levamisole prior to transportation. This may be due to the known fact that road transportation is an important stressor associated with free radicals formation which are known to play a role in tissue damage and have adverse effects on erythrocytes (Sumikawa et al., 1993; Avellini et al., 1995). It is also known that lipid peroxidation increases in plasma and tissues leading to damage to cell membranes (Sahin et al., 2001). However, decreases in PCV in healthy non stressed buffalo, heifers administered levamisole at $15 \mathrm{mg} \mathrm{kg}^{-1}$ has been reported (Zia-ur-Rahman et al., 2003). It however, contrasts with the observations of Mohri et al. (2005) who reported no significant changes in $\mathrm{PCV}$ in non stressed dairy calves administred levamisole orally at $2 \mathrm{mg} \mathrm{kg}^{-1}$ three times a day at 1 day interval. In another contrasting report, $\mathrm{PCV}$ was found to be increased in beef calves post transportation and may be attributed to dehydration and subsequent haemoconcentration. The total leukocyte values were not altered significantly. This agrees with the report of Ziprin et al. (1980) who determined the effect of levamisole administration in stressed cattle and observed no effect on haematological (granulocytic series) values. Mohri et al. (2005) also observed no alterations toatal leukocyte counts in non stressed neonatal dairy calves administered levamisole. This however, contrasts with the report of Sporer et al. (2008) who observed higher leukocyte values in young beef bulls post transportation and indicated that leukocytosis is one of the biomarkers of transport stress. Levamisole is also known to have a cholinergic effect on leukocytes and also increases protein and nucleic acid synthesis in resting leukocytes (Bourne et al., 1978), thus causing leukocytosis. The stress of transportation in this study may have superseded the effect of levamisole. No alteration was observed in the absolute lymphocyte values between the experimental and the control group. This agrees with the report of Mohri et al. (2005) in non stressed neonatal dairy calves administered levamisole. The significant 
increase in absolute neutrophil values between the experimental and control groups. This is in tandem with the observations of increased neutophil values in cattle transported by road (Tarrant et al., 1992). This however, contrasts to the report of Ziprin et al. (1980) who observed no effect in stressed cattle administered levamisole.

In non stressed cattle, Mohri et al. (2005) also observed a significant increase in neutrophil level on day 14 in dairy calves administered levamisole. The increase in neutrophil lymphocyte ratio observed in this study agrees with the findings of Kannan et al. (2000) who observed an increase in the neutrophil lymphocyte ratio associated with transportation stress in goats. The result is also in agreement with the established fact that the parameter is a good indicator of stress in goats and calves. In this study, we did not observe any changes in the absolute values of monocytes and eosinophils post transportation. This concurs with the observations of Kannan et al. (2000) in transported goats. Although, levamisole is known to increase phagocytosis by polymorphonuclear phagocytes and macrophages in a hypofunctional state of these cells (Vojtic, 1998), the stress of transportation may have suppressed the activity of the drug in enhancing phagocytosis.

\section{CONCLUSION}

This study shows that levamisole has little or no effect in reducing transport stress in sheep when administered at $15 \mathrm{mg} \mathrm{kg}^{-1} 30 \mathrm{~min}$ before transportation. The timing, dose of administration and extent of stress appears to limit the activity of immunomodulators such as levamisole.

\section{REFERENCES}

Atessahin, A., I. Karahan and I. Pirincci, 2004. Effects of therapeutic and toxic doses of levamisole on thyroid hormones and some biochemical parameters in sheep. Cell Biochem. Function, 22: 281-286.

Avellini, L., M. Silvestrelli and A. Gaiti, 1995. Traininginduced modifications in some biochemical defences against free radicals in equine erythrocytes. Res. Vet. Commun., 19: 179-184.

Ayo, J.O. and S.B. Oladele, 1996. Road transport stress in food animals in Nigeria. A review. Nig. Vet. J., 1: 49-57.

Babiuk, L.A. and V. Misra, 1982. Effect of levamisole in immune responses to bovine herpesvirus-1. Am. J. Vet. Res., 43: 1349-1354.

Bourne, F.J., T.J. Newby, P. Evans and K. Morgan, 1978. The immune requirements of the newborn pig and calf. Ann. Vet. Res., 9: 239-244.
Coles, E.H., 1986. Veterinary Clinical Pathology. 4th Edn., W.B. Saunders Co., Philadelphia, London, ISBN-13: 978-0721618289.

Kannan, G., T.H. Terrill, B. Kouakou, O.S. Gazal, S. Gelaye, E.A. Amoah and S. Samake, 2000. Transportation of goats: Effects on physiological stress responses and live weight loss. J. Anim. Sci., 78: 1450-1457.

Mohri, M., H.A. Seifi and S.H.Z. Sani, 2005. Effects of oral administration of levamisole on non-specific immunity, serum proteins and health in normal colostrum-fed neonatal dairy calves. Comp. Clin. Pathol., 13: 132-136.

Naylor, P.H. and J.W. Hadden, 2003. T cell targeted immune enhancement yields effective $\mathrm{T}$ cell adjuvants. Int. Immunopharmacol., 3: 1205-1215.

Sahin, K., N. Sahin, M. Onderci, S. Yaraloglu and O. Kucuk, 2001. Protective role of supplemental vitamin $\mathrm{E}$ on lipid peroxidation, vitamins $\mathrm{E}, \mathrm{A}$ and some mineral concentrations of broilers reared under heat stress. Vet. Med. Czech, 46: 140-144.

Sporer, K.R.B., P.S.D. Weber, J.L. Burton, B. Earley and M.A. Crowe, 2008. Transportation of young beef bulls alters circulating physiological parameters that may be effective biomarkers of stress. J. Anim. Sci., 86: 1325-1334.

Sumikawa, K., Z. Mu, T. Inoue, T. Okochi, T. Yoshida and K. Adachi, 1993. Changes in erythrocyte membrane phospholipid composition induced by physical training and physical exercise. Eur. J. Applied Physiol., 67: 132-137.

Symoens, J. and M. Rosenthal, 1977. Levamisole in the modulation of the immune response: The current experimental and clinical state. J. Reticuloendothelial Soc., 21: 175-221.

Tarrant, P.V., F.J. Kenny, D. Harrington and M. Murphy, 1992. Long distance transportation of steers to slaughter: Effect of stocking density on physiology, behaviour and carcass quality. Livest. Prod. Sci., 30: 223-238.

Thienpont, D., O.F. Vanparijs, A.H. Raeymaekers, J. Vandenberk and J.A. Demoen et al., 1966. Tetramisole (R 8299), a new, potent broad spectrum anthelmintic. Nature, 209: 1084-1086.

Vojtic, I., 1998. Levamisole caused association between neutrophil and eosinophil in dairy cows after parturition. Veterinarski Arhiv, 68: 135-142.

Zia-ur-Rahman, M.A. Sandhu and T. Ahmad, 2003. Haematological and serum biochemical profiles of buffalo heifers as influenced by levamisole. Comp. Clin. Pathol., 12: 147-150.

Ziprin, R.L., E.G. Steel, H.D. Petersen, M.H. Elissalde and M. McCartor, 1980. Haematologic study of effects of levamisole on stressed cattle. Am. J. Vet. Res., 41: 1884-1885. 